\title{
Teaching Vocabulary by Using Experiential Learning to The Students of MTsN 2 Banda Aceh
}

\author{
Sariakin $^{1 *}$, Muchsin ${ }^{2}$, Razali Abdullah ${ }^{3}$, Muslem Daud $^{4}$, Ratna Mutia $^{5}$ \\ ${ }^{1}$ English Departement, Faculty of Teacher Training and Education,Universitas Bina \\ Bangsa Getsampena, Banda Aceh 24415,Indonesia \\ ${ }^{2,3}$ English Departement, Faculty of Teacher Training and Education, Universitas \\ Serambi Mekkah, Banda Aceh 23245, Indonesia \\ ${ }^{4,5}$ Economy Departement, Faculty of Teacher Training and Education, Universitas \\ Serambi Mekkah, Banda Aceh 23245, Indonesia \\ *Corresponding Author: Sariakin, Email: sariakin@bbg.ac.id.
}

\begin{abstract}
The research aimed to find out if the students of MTsN 2 Banda Aceh who were taught vocabulary using experiential learning got a higher score than those who were taught without experiential learning. This research was conducted using pre-experiment with one class; pre-test and post-test design. The population of this research was the eighth-grade students. The total population of this study was 114 students composed of five classes; VIII-1, VIII-2, VIII-3, and VIII-4. Every class consists of about 28 students. The sample of this research was class VIII-1 of the eighth grade because the students' ability of this class was better than the other classes. The data were taken through the test. Then, the obtained data were analyzed by using the gain score (GS). The result of this research showed that the GS was 0.32. Meaning that there was a difference between the students' ability in mastering vocabulary before and after teaching using experiential learning and the difference was 0.32 points or $32 \%$. Therefore, the student's ability in mastering vocabulary increased $32 \%$ with experiential learning.
\end{abstract}

Keywords: Teaching, Learning process, Experiential learning, Vocabulary.

\section{Introduction}

In Indonesia, English is the first foreign language that is taught formally from junior high school level to the university. So that, the junior high school students are beginners in learning English. It is hoped that they will learn English more naturally as they learn their mother tongue. Besides, it will be the basis for the students to learn English at a higher level. According to Bortnem (2011), children enter kindergarten in the United States with large differences in their background knowledge, vocabulary, and early literacy experiences. There is a strong relationship between language development during the early years and reading ability in the primary grade and teachers must understand the importance of developing vocabulary and its relationship to literacy.

At Junior High School, English is introduced to the students through learning its vocabulary because vocabulary is the most important element that will become the basic competence to get other competencies like listening, speaking, reading, and writing (Depdiknas, 2006). If the students have mastered several vocabularies required at their level, it will be easier for them to master those elements in English learning. Vocabulary learning is an essential part of foreign language learning as the meanings of new words are very often emphasized, whether in books or classrooms. It is also central to language teaching and is of paramount importance to a language learner (Alqahtani, 2015). Therefore, vocabulary is an essential thing that has to be learned by the students to master English well.

According to Linse\& Nunan (2005), vocabulary is the collection of words that individuals know. Vocabulary is any kind of word that is used for communication. 
A vocabulary is several words that should be familiar to someone. In other words, vocabulary is the word capacity of someone when he or she applies four language skills (listening, speaking, reading, and writing). Without mastering enough vocabulary, students are not able to express their ideas clearly or understand a text. However, many students still get difficulties in mastering vocabulary thus their vocabulary mastery is not satisfying or low. Without mastering the vocabulary, a student will get difficulty learning English. By knowing the vocabulary from the beginning, the beginners will get a lot of knowledge and will not get difficulties in mastering language skills. Thus, vocabulary should be the priority in English language teaching and learning.

Based on the importance of vocabulary, teachers should give serious attention to teaching vocabulary, because it is a crucial thing in learning English. Teaching vocabulary to Junior High School students as beginners is not easy. There is a difference between teaching beginners and teaching adults. Teachers must have extra power to teach them and the beginners have certain characteristics and need a certain treatment. It is also the first chance of learning a foreign language. Thus, the teacher should find the best or the effective method to teach English vocabulary. Teachers will face some problems during the teachinglearning process. Even though, teachers have their priority to manage their classroom, as Richards (2013) stated that teachers have primary responsibility for how they teach; they may assume very different roles within their classroom. Thus, teachers should make their classrooms more comfortable and interesting, especially teaching English in Junior High School.

Based on the result of pre-research, we found that the students' vocabulary mastery was low. It was because the students got difficulties in mastering vocabulary. Some reasons: (1) the students got difficulties in grasping and memorizing the meaning of the words; (2) they found it was difficult to spell the words correctly; (3) they got difficulties in pronouncing the words correctly; and (4) they got difficulties in using the vocabulary in a sentence. They were able to use the vocabulary if they knew the meaning, how to pronounce, how to spell, and how to use them in a sentence. Knowing the meaning of some words did not merely know their translation in different languages. Knowing means understanding how the words were put in different contexts and used differently. For example: good morning. The students not only know that good morning is "Selamat Pagi" in Indonesian language, but they can greet someone in the morning using "good morning". How to pronounce can be understood from pronouncing the words correctly. Students can distinguish the slightly different words such as tree and three. English has a more complex pronunciation than Indonesian language, and it often becomes a problem. It will be a difficult thing when the words are similar to the others. For example, "sea" and "see". Usually, it is tightly connected with knowing words. When students understand the word, they will be able to indicate whether to spell sea or see. How to use words is an ability to use or to apply the words either in spoken or written. For example, a student says, "jump to the left" when the teacher says "jump". On another occasion, the student says: "jump to the chair". In this case, of course, the student has already understood how to use the word jump in different contexts.

By conducting observation and interviews, we also found some psychological barriers from the students. They felt shy and afraid to ask the teacher if they found a difficulty. These problems might give a great influence on their learning process. Other reasons that cause the students' failure was the teacher's teaching method. The teachers were not creative when teaching a foreign language to children. Sometimes it makes the students got bored and they also felt that the teaching method didn't give them more chances to internalize the words in their memory. In teaching English in Junior High School, the method used should be communicative and suited to the students' characteristics as children. 
It is aimed to create a teaching-learning process that is interesting and comforting to the students so that they can reach the learning goal and English becomes a more attractive subject for them. From the reason above, we suggested the experiential learning method as the solution. Experiential learning methods can be used in teaching vocabulary to make the teaching-learning process much interesting and fun. It would increase students' interest in the learning process in the classroom because the circumstances become more interesting. It is suitable with the characteristics of the young learners who like playing and talking about 'here and now' so experiential learning can help teach vocabulary.

Next, according to Kolb (2015), experiential learning is a powerful and proven approach to teaching and learning that is based on one incontrovertible reality: people learn best through experience. Furthermore, Kolb's framework addresses the current organizational and educational landscape, and features current examples of experiential learning both in the field and in the classroom. It will be an indispensable resource for everyone who wants to promote more effective learning. Experiential learning offers some potential benefits not only for students' language development, but also for strengthening their independent learning, building motivation, and cultural understanding. Nevertheless, there are some shortcomings of the use of experiential learning in TEFL such as linguistic demand beyond students' level and the use of mother tongue during the project accomplishment (Safriani, 2015).Based on the reasons above, we used the experiential learning method as the method to improve students' vocabulary mastery of MTsN 2 Banda Aceh.

\section{Method}

\section{Research Design}

The design used in this research was pre-experiment; one group: pretest - posttest. In this design, there was one class; pre-test was conducted before treatment, and posttest was conducted after treatment. This treatment was made for the experiment to determine the effects of a given treatment.Next, the research paradigm of one group: pretest-posttest can be drawn in Table 1.

Table 1. Research Paradigm

\begin{tabular}{ccc}
\hline Pretest & Treatment & Posttest \\
\hline $\mathrm{O} 1$ & $\mathrm{X}$ & $\mathrm{O} 2$
\end{tabular}

\section{The Population and Sample}

The population of this research was the eight-grade students of MTsN 2 Banda Aceh. The total population of this study was 114 students composed of four classes; VIII-1, VIII-2, VIII-3, and VIII-4. Every class consisted of about 28 students. The sample of this research was class VIII-1 at second grade of MTsN 2 Banda Aceh. We used the purposive sampling technique in choosing a sample. We chose the students in the class VIII-1 because the students' ability of the class is better than the other classes.

\section{The Research Instrument}

This study used a test. The test consists of two tests; pretest and posttest. The pretest is an activity that tests the level of students' knowledge of the material to be delivered, pretest activities are carried out before the teaching activities are given. Post-test is the final evolution when the material taught on that day has been given which a teacher assigns to the students. The benefit of this posttest is to get an idea of the capabilities achieved after the end of the lesson delivery. The result of this post-test was compared to the pretest result that has been done thus it will be known how far the effect or influence of teaching has been done.

\section{Data Analysis}

In this research, we applied quantitative data. The quantitative data was used t-test to analyze the score of the students. To know the difference of the test success after using 
experiential learning and to find out the differences between pre-test and post-test, the writer used the following formula suggested by Creswell (2008).

$$
G S=\frac{\mathrm{O}_{2}-\mathrm{O}_{1}}{\text { MaxScore }- \text { pretest }}
$$

Where, GS is Gain Score, O2 is the average score of the posttest, O1 is the average score of the pretest. Max score is 100, and pretest is the average score of the pretest.

\section{Results}

After getting the data, we calculated the average score of pretest and posttest that was gotten by the students, and to find out the average score, we calculated the data using SPSS Version 22. The result of the calculation is shown in Table 2.

Table 2. The Students' Average Score of Pretest and Posttest

\begin{tabular}{cccccc}
\hline & Test & N & Mean & $\begin{array}{c}\text { Std. } \\
\text { Deviation }\end{array}$ & $\begin{array}{c}\text { Std. Error } \\
\text { Mean }\end{array}$ \\
\hline Score & Pretest & 28 & 58.04 & 6.432 & 1.216 \\
& Posttest & 28 & 71.61 & 8.284 & 1.565 \\
\hline
\end{tabular}

Table 2 shows that the average score of the pretest was 58.04 in mastering vocabulary. Meanwhile, the average score of the posttest was 71.61 in mastering vocabulary. The average score of the pretest was gotten before the students were given the treatment. Meanwhile, the average score of the posttest was gotten after the students were given the treatment. Furthermore, the student's average score of the post-test was higher than the students' average score of the pretest. Thus, the student's ability in mastering vocabulary after they were taught vocabulary using learning experiential learning was better than before they were taught vocabulary using learning experiential learning.

Next, we calculated the data of pretest and posttest to find out if the usage of learning experiential learning in teaching vocabulary was better than the common way or the usage of experiential learning in teaching vocabulary was not better than the common way. The result of the calculation was presented in the following formula of difference between pretest and posttest.

$$
\begin{gathered}
G S=\frac{O_{2}-O_{1}}{\text { MaxScore }- \text { pretest }} \\
G S=\frac{71.61-58.04}{100-58.04} \\
G S=\frac{13.57}{41.96}=0.32
\end{gathered}
$$

Based on the statistical analysis, it was found that the GS was 0.32. It means there was a difference between the students' ability in mastering vocabulary before and after they were taught using experiential learning and the difference was 0.32 points or $32 \%$. Therefore, the student ability in mastering vocabulary increased $32 \%$ after they were taught using learning experiential learning.Next, it can be concluded that the usage of learning experiential learning in teaching vocabularywasbetter than without using learning experiential learning. In the other words, it can be stated that the use of learning experiential learning in teaching vocabularywasbetter than without using learning experiential learning.

In addition, the frequency score of the pretest is presented in Table 3. 
Table 3. The Frequency Scores of Pretest

\begin{tabular}{cccccc}
\hline & Frequency & Percent & $\begin{array}{c}\text { Valid } \\
\text { Percent }\end{array}$ & $\begin{array}{c}\text { Cumulative } \\
\text { Percent }\end{array}$ \\
\hline \multirow{6}{*}{ Valid } & 50 & 6 & 21.4 & 21.4 & 21.4 \\
& 55 & 9 & 32.1 & 32.1 & 53.6 \\
& 60 & 6 & 21.4 & 21.4 & 75.0 \\
& 65 & 4 & 14.3 & 14.3 & 89.3 \\
& 70 & 3 & 10.7 & 10.7 & 100.0 \\
& Total & 28 & 100.0 & 100.0 & \\
\hline
\end{tabular}

Table 3 shows the that 6 students $(21.4 \%)$ got a score of $50 ; 9$ students $(32.1 \%)$ got a score of 55; 6 students (21.4\%) got a score of $60 ; 4$ students $(14.3 \%)$ got a score of 65 ; and 3 students $(10.7 \%)$ got a score of 70 .Base on the description, most students got a score of 55 in mastering vocabulary. Then, we presented the frequency score of the pretest in Figure 1.

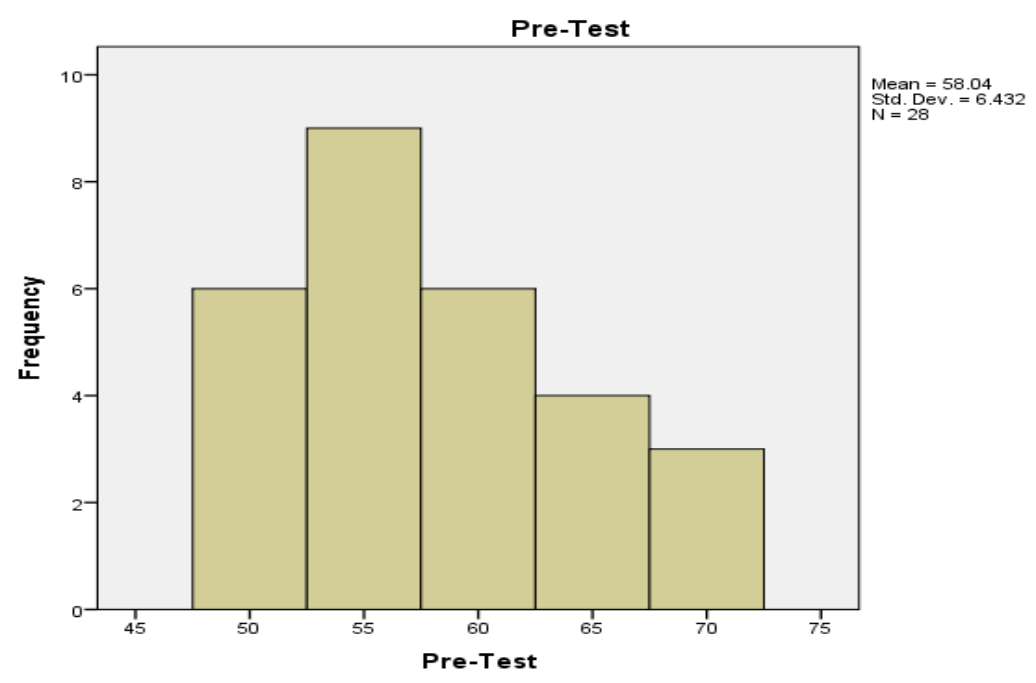

Figure 1. Histogram of Pretest

Next, the frequency score of the posttest can be presented in Table 4.

Table 4 Frequency Scores of Post-Test

\begin{tabular}{cccccc}
\hline & & Frequency & Percent & Valid Percent & Cumulative Percent \\
\hline \multirow{6}{*}{ Valid } & 55 & 1 & 3.6 & 3.6 & 3.6 \\
& 60 & 3 & 10.7 & 10.7 & 14.3 \\
& 65 & 4 & 14.3 & 14.3 & 28.6 \\
& 70 & 9 & 32.1 & 32.1 & 60.7 \\
& 75 & 4 & 14.3 & 14.3 & 75.0 \\
& 80 & 3 & 10.7 & 10.7 & 85.7 \\
& 85 & 4 & 14.3 & 14.3 & 100.0 \\
& Total & 28 & 100.0 & 100.0 & \\
\hline
\end{tabular}

In Table 4, 1 student (3.6\%) got 55; 3 students (10.7\%) got $60 ; 4$ students $(14.3 \%)$ got $65 ; 9$ students $(32.1 \%)$ got 70,4 students $(14.3 \%)$ got $75 ; 3$ students $(10.7 \%)$ got 80 , and 4 students (14.3\%) got 85.Based on the description, we concluded that most students got a score of 70 in mastering vocabulary. In addition, we presented the frequency score of the posttest in the following histogram (Figure 2). 


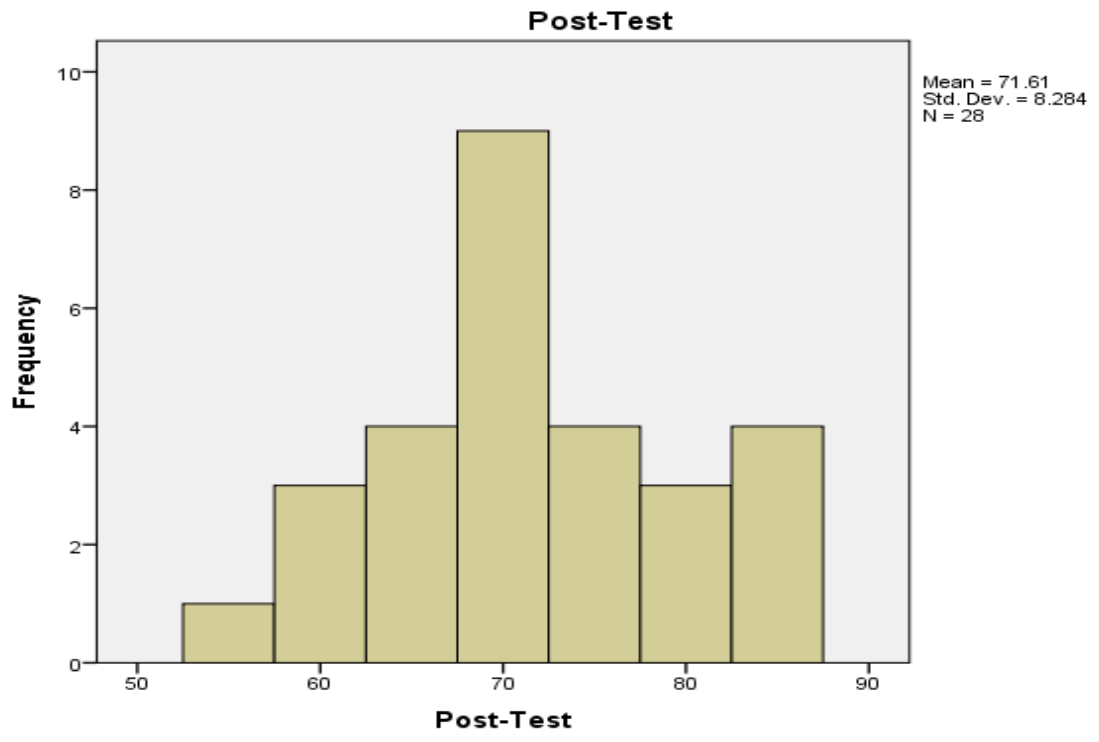

Figure 2. Histogram of Post-Test

The data collected on the students' opinion of MTsN 2 Banda Aceh in learning a reading skill by using experiential learning. Based on the data findings of the questionnaire, we found that (1) most students (40\%) agreed very much that the use of experiential learning can increase their vocabulary; (2) most students $(46.7 \%)$ who disagreed that the use of English and Indonesian together in instruction can spoil language elements; (3) most students $(33.3 \%)$ agreed that usage of experiential learning can increase the students' motivation in reading books written in English; (4) most students (33.3\%) disagreed very much that usage of experiential learning can repress local language; and (5) most students $(40 \%)$ agreed very much that the usage of experiential learning made the students more diligent to find new vocabularies in the dictionary.

\section{Discussion}

Since the design used one sample; pretest and posttest, thus, pretest must be given to the students before experiment. Next, the result of the pretest showed that the students' average score was 58.04. Furthermore, the student's average score of the pretest was 71.61 after they were taughtusing experiential learning in vocabulary instruction. Thus, the student ability in mastering vocabulary before treatment was 58.04 and it was not very satisfying. It happened because the method used by teachers was not appropriate for the student character. Thus, it affected the students' interest and motivation in learning vocabulary.

Therefore, we tried to improve the students' ability in mastering reading skills by conducting a teaching and learning process of vocabulary through experiential learning. After we taught reading skills to the students using experiential learning, the student ability in mastering vocabulary increased and the increase was about $32 \%$. The students' ability in mastering vocabulary increased because they enjoyed following teaching and learning processes. Next, the use of experiential learning in the teaching and learning process makes the students happy and motivated to follow the teaching and learning process.

Then, after we gave a pretest and analyzed it, we conducted the teaching and learning process (treatment) of reading skills using experiential learning. After conducting the teaching and learning process of reading skills, we conducted a posttest. The result of the posttest in which the average score of the posttest (68) was greater than the average score of the pretest (58). Thus, the use of Experiential Learning in teaching vocabulary to the students of MTsN 2 Banda Aceh was effective to improve the students in mastering vocabulary.

Next, the student interest and motivation increased when they were taught using 
experiential learning. Therefore, their ability in mastering vocabulary was better through experiential learning. In addition, based on the data findings of the questionnaire, we found that (1) most students agreed very much that the use of the English language as a medium of instruction can increase their vocabulary; (2) most students who disagreed that the use of English and Indonesian together in instruction can spoil language elements; (3) most students agreed that usage of English as the language of instruction can increase the students' motivation in reading books written in English, (4) most students disagreed very much that usage of English as the language of instruction can repress local language; and (5) most students agreed very much that the usage of English as the language of instruction made the students more diligent to find new vocabularies in the dictionary. Finally, the use of Experiential Learning in the teaching and learning process was a new effective strategy to be used in teaching vocabulary at MTsN2 Banda Aceh.

\section{Conclusions}

Based on the results of the study and the analysis, it can be concluded that the students' ability of MTsN 2 Banda Aceh were in good category because their average score was 68 after using English as the language of instruction. Their ability increased $32 \%$ after using experiential learning Thus, teaching reading skills to the students of MTsN 2 Banda Aceh using experiential learning was successful because the students' ability in mastering vocabulary increased. The usage of experiential learning in teaching reading skills was better than the common way. It can be proved that the difference between pretest and posttest was 0.32 points. The students' motivation of MTsN 2 Banda Aceh increased when they were taught vocabulary by using experiential learning.

\section{References}

Safriani, A.(2015). Experiential Learning for Language Teaching: Adapting Kolb's Learning Cycle in Teaching English as a Foreign Language. Prosiding Halaqoh Nasional \& Seminar Internasional, Pendidikan Islam Fakultas Tarbiyah dan Keguruan, UIN Sunan Ampel Surabaya. 378-383.

Bortnem, G. (2011). Teacher Use of Interactive Read Alouds Using Nonfiction in Early Childhood Classrooms. Journal of College Teaching and Learning, 5(12), 29-44.

Creswell, J. W. (2008). Educational Research: Planning, Conducting, and Evaluating Quantitative and Qualitative Research. New Jersey: Pearson Education.

Kolb, D.A. (2015). Experiential Learning: Experience as the Source of Learning and Development. London: Pearson Education.

Depdiknas. (2006). Kurikulum Tingkat Satuan Pendidikan. Jakarta: Depdiknas.

Richards, J.C. (2013). Curriculum Approaches in Language Teaching: Forward, Central, and Backward Design. RELC Journal, 44(1), 5-33.

Linse, C.T., \& Nunan, D. (2005).Practical English Language Teaching: Young Learners. New York: McGraw-Hill/Contemporary.

Alqahtani, M. (2015).The Importance of Vocabulary in Language Learning and How to Be Taught. International Journal of Teaching and Education, 3(3), 21-34. 